Котов А. Э. Публицисты катковского направления против левого радикализма (вторая половина 188о-х гг.) // Философия. Журнал Высшей школы экономики. -2018 . - Т. II, № 2 . - C. $33-47$.

\title{
AлEKCAHAP Котов*
}

\section{ПУБЛИЦИСТЫ КАТКОВСКОГО НАПРАВЛЕНИЯ ПРОТИВ ЛЕВОГО РААИКАЛИЗМА

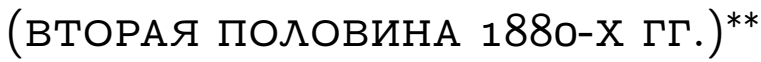

Аннотация: Одной из главных задач консервативной печати М. Н. Катков считал содействие властям в борьбе с революцией. Первоначально Катков считал русский нигилизм следствием «польской интриги». Но уже первые покушения на Александра II показали, что революция имеет внутреннюю природу. K концу 1860-х годов тема «польской интриги» отходит в антинигилистическом дискурсе на второй план. И Катков, и его сотрудники все чаще ищут истоки революции внутри самого русского общества. На рубеже 1870-1880-х годов широкий резонанс получили антиреволюционные памфлеты Н. А. Любимова, Н. Н. Голицына, П. П. Цитовича, М.Ф. Ае-Пуле. Но выходили в этот период работы и иного рода. Немалый интерес представляет подготовленный С. С. Татищевым для ІІІ отделения «Обзор социально-революционного движения в России». Издание не предназначалось для широкой публики, и это давало автору определенную свободу - в частности, он признавал правоту отдельных тезисов теоретиков социализма, но русских нигилистов считал маргиналами. Схожим был подход И.Ф. Циона. С середины 1870-х гг. он проживал за границей и также имел возможность соотнести русскую революционность с европейским контекстом. Установление во Франции республики только доказало, по его мнению, все ничтожество левых. Столь же презрительно относился к французским республиканцам и главный парижский корреспондент Каткова-Н. В. Щербань. В своих корреспонденциях для газеты «Голос» он рисовал яркую панораму революционных событий начала 1870-х гг. Перейдя в «Московские ведомости», Щербань стал уделять основное внимание русскому революционному зарубежью. В 1887 г. вышел его памфлет под названием «Политический разврат», содержавший выпады как против народовольцев и их теоретиков, так и против проникавших в русскую революционную среду марксистских идей. Опираясь на материалы эмигрантской печати, Щербань убедительно доказывал теоретическую слабость революционного нигилизма.

Ключевые слова: консерватизм, нигилизм, революция, марксизм, народничество, М. Н. Катков, Н. В. Щербань.

DOI: $10.17323 / 2587-8719-2018-$ II-2-33-47.

Наиболее известный отечественный консервативный публицист М. Н. Катков считал главной задачей охранительной печати помощь «добрым

*Котов Александр Эдуардович, д. ист. н., доцент Санкт-Петербургского государственного университета, a.kotov@spbu.ru.

** (C) Котов, А.Э. (C) Философия. Журнал Высшей школы экономики. Исследование выполнено при финансовой поддержке РФФИ, проект «Дневник А. В. Богданович (1879-1890 гг.)» № 17-01-00021. 
людям в изловлении беспутных бродяг и воришек» (Катков, 1861: 483). K последним московский публицист причислял всех, кто покушался на целостность и гомогенность русского государственного организма. Как известно, и русский революционный экстремизм, и нарождавшийся украинский национализм представлялись редактору «Московских ведомостей» результатами деятельности «польской интриги», напрямую заинтересованной в распаде русской «политической нации».

В этой «конспирологии» имелось и рациональное зерно: Катков и его единомышленники стремились таким образом подчеркнуть внешний характер революционной угрозы. Впрочем, уже первые покушения на Александра II показали, что последняя имеет внутреннюю природу. К концу 1860-х гг. тема «польской интриги» отходит в антинигилистическом дискурсе на второй план. И Катков, и авторы публиковавшихся на страницах его изданий антинигилистических романов, и политические публицисты катковского круга-все они всё чаще ищут истоки революции внутри самого русского общества: в невежестве и «полуобразованности» разночинной молодежи, в космополитизме аристократической и бюрократической элиты. Читатели катковских изданий выносили из них впечатление, что «нигде так много не толкуют о нигилизме, как в п[етер]б[ургских] гостиных, но нигде также нет столько людей, их распложающих, как именно в этих salons du grand monde (салонах большого света)» (Богданович, 1880: 1360б.).

Специфически-утилитарные задачи подобной критики «революционного нигилизма» делали излишним глубокий анализ идеологии революционного движения и выявление внутри него различных направлений:

Не все ли равно, под каким соусом нас съедят, когда все согласны между собою в том, что съесть нас необходимо, что общественный и государственный строй России нужно разрушить до основания, что из всего здания, носящего еще название Русской империи, не следует оставлять камня на камне (Цион, 1886: 9).

Ничто не мешало и расширению трактовок терминов «нигилизм» и «революция». Так, в 1890-е гг. Л. А. Тихомиров (сам, впрочем, одним из первых консерваторов отошедший от сформулированного Ционом подхода) выразил довольно стандартную для консервативной публицистики мысль: «Не подлежит [...] никакому сомнению, что в личном составе, как и в идейном отношении, между чисто революционным и конституционным движениями нельзя провести резкой разницы» (Тихомиров, 1997: 219). Как следствие, антиреволюционный полемический 
арсенал можно было пополнять, например, указаниями на злоупотребления западных конституционных режимов.

На рубеже 1870-1880-х гг. широкий резонанс получили антинигилистические и антиреволюционные памфлеты Н. А. Любимова, Н. Н. Голицына, П. П. Цитовича, М. Ф. Де-Пуле. Де-Пуле искал истоки нигилизма в системе образования (Котов, 2016а), а Цитович-в крепостном праве (Котов, 2015). Любимов объяснял французскую революцию либеральными уступками правительства (Котов, 2012). Князь же Николай Голицын напоминал своим оппонентам о теории Дарвина: «За нами-Бог и Русь, за вами - коммуна и обезьяна» (Голицын, 1879: 12). Но выходили в этот период работы и иного рода.

Немалый интерес представляет подготовленный С. С. Татищевым «Обзор социально-революционного движения в России», напечатанный в 1880 г. «по распоряжению ІІІ Отделения Собственной Его Императорского Величества Канцелярии». Издание не предназначалось для широкой публики, и это давало автору определенную свободу. Кроме того, во время написания книги Татищев еще не вошел в круг «птенцов гнезда Каткова» - и влияние на него харизматичного «московского громовержца» было куда менее значительным. Долгая жизнь и служба за границей также дали Татищеву возможность взглянуть на революционное движение несколько иначе.

Корни революционного движения бывший дипломат искал на Западе - прежде всего, во Франции. В тяжких условиях политической нестабильности и плюрализма мнений поиски французской общественной мыслью «более устойчивых или, что то же, более истинных форм общественной и государственной жизни» не могли не сопровождаться спорами, «подтасовкой фактов и освещения их различными фактами по их усмотрению»-а следовательно, «исторический метод естественно уступал место гипотетическому». Это и привело к популярности в стране различных социальных утопий. В качестве любопытной тенденции развития социалистической мысли середины XIX в. Татищев отмечал, что ее идеологи все чаще приходят к отрицанию собственно демократических практик. Характеризуя же русское революционное движение 1860-х, Татищев причислял его участников к «измельчавшему поколению». Исключением на этом фоне представлялась ему лишь фигура Бакунина«злого гения всякой социальной реформы» (Котов, 2016b: 287-289).

Однако все это не мешало Татищеву отчасти соглашаться с социалистами: с «едкими упреками» Бакунина по адресу французской буржуазии, с наличием объективных социально-экономических причин для 
народного недовольства, со словами Лассаля и Маркса о наличии на Западе бесправия рабочих. По мнению Татищева, «движение четвертого сословия к эмансипации», требовавшее от государственной власти «покровительства их справедливым требованиям», возникло не благодаря, но вопреки социалистическим «работникам мысли»-вносившим в эту борьбу «только недоумение и смуту». Русских же революционеров Татищев считал прежде всего маргиналами. Последние не представляли бы опасности «при цельности общества, при непоколебимости его консервативных элементов». В условиях же дряблости общества, способного лишь «выделять из весьма разнообразных слоев своих контингент для пополнения [...] врагов его собственного благосостояния», государство, по убеждению Татищева, оставалось единственной «силою, от которой общество ждет своего возрождения из пепла, силою, которая одна только в состоянии восстановить в его основе незыблемые консервативные начала» (Котов, 2016b: 287-288).

Схожим был подход к революционному движению и другого знаменитого «катковца»- И. Ф. Циона. Этот профессор-физиолог, ушедший из Медико-хирургической академии в результате конфликта с революционным студенчеством и либеральной профессурой, также считал, что «в пресловутых идеях нашего нигилизма весьма мало оригинального, что они только бледные снимки с идей величайших извергов эпохи террора во Франции». Он отмечал теоретическую слабость народнических воззрений: «их группа [...] в течение 10-15 лет чуть не каждый месяц меняла свою систему, свою программу действия, свое название». Нигилизм рассматривался И. Ф. Ционом как разновидность эпидемической болезни, а потому главный объект его критики - не сами «микробы», а «санитарные власти», «давшие заразе развиться»; «пагубная небрежность публики, [...] не нашедшей в себе достаточно энергии, чтобы собственною инициативой заменить отсутствие правительства»; наконец, те «развратители юношества, которые в стенах университетов и на столбцах журналов систематически вливали в молодые умы яд и сознательно, из-за пошлой популярности, губили целые поколения [...] русского юношества» (там же: 263-265).

С середины 1870-х гг. Цион проживал за границей и имел возможность соотнести русскую революционность с европейским - прежде всего французским - контекстом, а также с результатами революционного движения на Западе. В 1885 г. на страницах «Русского вестника» появился очерк Ильи Фаддеевича о новейшей французской истории. Цион отмечал, что после 1789 г. во Франции «ни одна форма правления 
не могла продержаться более полутора десятка лет» (Цион, 1885a: 462). Любопытно его рассуждение о причинах революции 1870 г.:

Человек, спокойно обсуждающий исторические события в мирной тиши своего кабинета, может находить, что революции в эпоху вторжения внешних врагов и как бы на глазах иностранного завоевателя есть акт непатриотический; он без труда даже докажет, что для самих республиканцев было бы благоразумнее предоставить империи, столь легкомысленно начавшей народную борьбу, довести ее до конца и понести тяжелое бремя постыдного мира. Но тридцатимиллионное население, совершенно обезумевшее от беспримерных в истории поражений, пожираемое лихорадкою патриотического гнева и стыда, не может сложа руки спокойно обдумывать всевозможные последствия своих действий. Императорское правительство пало столько же под тяжестью собственных ошибок, сколько под ударами грозного завоевателя (там же: 463).

Свершившаяся революция, по мнению Циона, доказала все ничтожество республиканцев, равно развеяв мифы и о непобедимости революционных «легионов», и «о любви к свободе и неподкупной честности республиканцев»: «Эта последняя легенда была гораздо менее распространена, чем первая, и находила верующих только среди поколения, выросшего после 1851 года. Но в стране, где в 21 год каждый становится избирателем, и эта легенда была не без влияния на результаты выборов» (там же: 466). Цион был убежден, что разочарование в республиканцах было всеобщим, и только отсутствие единства среди монархистов помешало восстановлению монархии. Последующее же экономическое возрождение Франции произошло «не благодаря республике, а несмотря на республику» (там же: 478). Отношение министров-республиканцев к собственной стране профессор сравнивал с поведением колонизаторов:

Для этих господ Франция до тех пор, как они стали у кормила, точно вовсе не существовала. Это была дикая страна: без дорог, без школ, [...] без литературы и искусств, чем-то вроде провинции Тонкина, в которой монархисты, бонапартисты и другие консерваторы играли роль Черных флагов. Завоевав страну, республиканцы сочли долгом цивилизовать ее. Все пришлось переломать, переобразовать и создать, а для этого потребовались деньги и деньги (там же: 497).

Цион обвинял республиканцев в разрушении армии, преследовании религии и продажности: «Революционные идеи превратились в предмет торговли, и любой радикал охотно покидает свою революционную пропаганду и свое призвание спасать человечество, как только ему 
доставляет более доходное место в какой-нибудь другой отрасли: в торговли, промышленности или даже в администрации» (Цион, 1885a: 507). Терпимость же революционеров к религии была, по его мнению, невозможна в принципе:

Между религией, предписывающей любовь к страждущим массам, стремящейся устранить из сердец младшей братии чувства ненависти и зависти к счастливцам мира, постановляющею в обязанность прощение обид и утешающею несчастных вознаграждением в другом мире за перенесенные страдания в здешнем, между этою религией и революцией, эксплуатирующей массы вызываемою ненавистью и завистью, возбуждающею месть и уверяющею страдальцев, что посмертное возмездие ложь и что только земные вожделения реальны, между этими двумя абсолютными противоречиями соглашение невозможно. Они смертельные враги, и борьба между ними будет продолжаться без пощады с обеих сторон (Цион, 1885b: 153).

Столь же презрительно относился к французским республиканцам и главный парижский корреспондент Каткова-забытый ныне Н. В. Щербань. Живя в начале 1870-х во Франции, первоначально он посылал корреспонденции в либеральный «Голос». Вращаясь в это время по преимуществу в республиканских кругах, Николай Васильевич знал эту среду «не по ораторским упражнениям, которыми они заманивают, a - au natural».

Неприязнь Щербаня к «освободительному движению» чрезвычайно усилилась во время Парижской коммуны. В его корреспонденциях из Бордо и Версаля (временных столиц «контрреволюционных» сил) находили отражения самые красочные слухи из охваченной мятежом «столицы мира»: «Столица Вселенной!.. Столица новой Каледонии, центр демагогического людоедства - вот это так!..» Подробно описывался Щербанем царивший в городе революционный террор, самыми черными красками изображалась и Коммуна, «самый комитет, овладевший Парижем». Любые попытки компромисса с мятежниками казались Николаю Васильевичу недопустимыми:

Соглашение с патентованными и открытыми врагами всякой тени какого бы то ни было, хотя бы даже демагогического, но правильно организованного общественного порядка! Уступки кровожадным фантазерам, которые если бы победили, то перевешали бы всех антагонистов; политическим воришкам, которые завели в пределах своего господства формальное государственное и частное воровство со взломом! (Котов, 2016b: 154-166) 
После разрыва с «Голосом» Щербань посылает свои корреспонденции в «Московские ведомости». Здесь он гораздо больше внимания уделяет русскому революционному зарубежью-тем более, что, проживая в Париже, он имел практически неограниченный доступ к ее печатной продукции. Так, в июне 1875 г. на страницах «Московских ведомостей» появился обширный очерк Щербаня «Возрождение русской печати за границею», посвященный возобновлению литературной активности революционной эмиграции, прекратившейся было после смерти А. И. Герцена и разгрома Парижской коммуны (Котов, 2016b: 175-176). В дальнейшем Щербань также не упускал возможности затронуть столь важную для редакции тему. Во второй половине 1887 г. на страницах «Русского вестника» появился его обширный памфлет под названием «Политический разврат», содержавший полемические выпады как против народовольцев и их теоретиков, так и против проникавших в русскую революционную среду марксистских представлений.

Прежде всего Николая Васильевича интересовала мотивация, толкнувшая революционеров на «непрошенное зверское вмешательство»т. е. на террористические акты. Выписав некоторые ходячие фразы из зарубежных изданий - «Вестника народной воли», «Общего дела», различных сочинений Степняка-Кравчинского, Лаврова и еще не перешедшего в консервативный лагерь Тихомирова-Щербань характеризовал их как «глухое нытье и неуловимые в своей широковещательности причитания»:

«Не нас одних, всю стомиллионную нацию душат, давят». «Страдания ее беспримерны в летописях деспотизма». «Россия лишена всяких прав.»«Не имея самых элементарных человеческих прав, русские люди являются породой червей». «Россия страна бесправная и угнетенная во всех человеческих побуждениях».- «Правительство держит Россию в рабстве, примеры которого можно найти теперь только в азиатских и африканских деспотиях». «Всякое сознательное прикосновение к жизненному общественному прогрессу, в силу полицейских условий, слишком опасно». «Душат все проявления здоровой жизни страны». «Что прикажете делать и чем заниматься у нас человеку честному, находящемуся в должном обладании умственными способностями, когда всякая нормальная деятельность строго преследуется». «Русское самодержавие - вред не только для русского народа, но и для всего человечества, над которым эта система висит грозой истребления всех прав, вольностей и приобретений цивилизации...» (Щербань, 1887а: 10).

В ответ на это жестокосердный публицист «Русского вестника» требовал уточнить: 
Каких именно человеческих прав лишены российские люди-черви? Какие побуждения угнетаются? Куда загорожен путь? Какое «прикосновение» к жизненному процессу не допускается полицейскими условиями? Какие проявления жизни задушены? Что подразумевается под должным обладанием умственными способностями и нормальною деятельностью... (Щербань, 1887а: 10).

Проживавший в Париже Щербань был, тем не менее, убежден в том, что

Россия, конечно, не рай, которого не существует на земле со времен грехопадения, но далеко и не ад, из которого следовало бы выводить невинных страдальцев, да еще путем терроризма. В России живется легче, чем где бы то ни было, потому что громадному большинству в ней обеспечено существование и потому что прочие классы не сталкиваются в ней на каждом шагу с беспощадною конкуренцией, заслоняющею на Западе все дороги начинающему; так что честный труд имеет в ней более чем где-либо шансов успеха. Он всегда найдет в ней «что делать и чем заняться», но труд честный, не презирающий своих обязанностей, может быть скоромный труд, а не то ветрогонство, заносчивость или шарлатанство, которое скучая серьезным делом или брезгуя им, предпочитает бить баклуши, широковещательствуя об устройстве судеб страны посредством безбожия, безначалия и грабежа по последнему слову науки (там же: 11).

В русской сельской общине Щербань видел ту же степень самоуправления, «что у сельских общин Швейцарии и Норвегии», налоги представлялись ему сопоставимыми с французскими, а проблема крестьянского малоземелья должна была, по мнению публициста, решиться по мере уже идущего постепенного и свободного перехода помещичьих. Наконец, крестьянскую нужду Щербань связывал с «недостатком уменья пользоваться своею землей» и задавался риторическим вопросом: «При чем же тут правительство и государственный строй, и уж не терроризм ли научит недостающему уменью»? (там же: 16).

Не будучи консерватором, Щербань был твердым сторонником эволюционного развития. В частности, его возмущала критика теоретиком народничества крестьянских банков, «забракованных им на том основании», что «крестьяне могут покупать только ту землю, что владелец хочет продать», т. е. из-за отсутствия в этих учреждениях «принудительного элемента». По этому поводу Щербань заметил, что нигилизм «не может высказаться, чтобы не показать кончика волчьего хвоста» (там же: 12). 
Отрицал публицист и другие поводы к недовольству существовавшими в России порядками: ограничения свободы слова, университетской автономии и полномочий земств. Цензурные послабления 1860-х гг Щербань расценивал как беспримерное в европейской истории «литературное кование „революционного оружия“, создание „революционной интеллигенции“, подготовление переворота»-которым в 1880-х гг. был наконец-то «положен некоторый предел» (Щербань, 1887a: 19). Осуждал публицист и стремление левых превратить земство из «орудия мирного провинциального прогресса» в «орудие всероссийской агитации и интриги» (там же: 44).

Наконец, вполне катковскими были оценки Щербанем университетской автономии 1860-х гг.: «Студентам внушалось, что [...] экзамены - „насилие, возмущающее нравственное чувство“; что „преподавание только тогда полезно, когда профессор имеет известные политические взгляды“» (там же: 24). Как следствие,

мало-помалу искусственно выработался тип студента, который в припадке откровенности «народовольческий» официозный орган называет теперь «студентом улицы», характеризуя его тем, что он чересчур чутко и «большею частью в ущерб своим занятиям отзывался на все общественные злобы дня и страдал существенными недостатками: скорою возбудимостью, непомерною резкостью, ленивым поверхностным отношением к университетской науке и малою культурностью». На этом несчастном юноше, воплотившем собою французскую карикатуру с подписью «прочь книги! Мы студентствуем не для того, чтоб учиться, а для того, чтобы давать уроки правительству»- на «обработке» «неопытности и мужества» вот этого несчастливца сосредоточились старания революционных ловцов (там же: 25-26).

Все это «нигилистическое обращение с фактами» было следствием «народовольческой нравственности», которая, по мнению публициста,

состоит в отсутствии всякой нравственности, в замене вечной правды и справедливости революционными пользами и нуждами данной минуты, в подчинении нравственному закону лишь до тех пор, пока он не стесняет мерзких поступков, признаваемых «целесообразными»: на эти последние «требования нравственности не распространяются» (там же: 51).

Революционеры представали в памфлете как «социалистические маркизы де-Сады» (Щербань, 1887b: 574), «политические развратники, открыто попирающие справедливость и нравственность» (Щербань, 1887a: 52). 
Революционное сознание народников стало поводом для проникновенного морализаторства:

И когда, в час окончательной проверки бытия, лицемер социалистической нравственности станет подводить духовный итог своей жизни, что скажет он окружающим его изголовье унылым призракам «малых сих», из прекрасного далека натравленных им на злодейство и подброшенных под возмездие? Что пролепечет он окровавленным теням мучеников, погибших от руки последователей его учения? Спокойно воззрит он на унылые призраки и обагренные кровью тени, потому что учение его [...] погубило одних и заклало других в осуществление превысших даже самой высшей нравственности обязанностей и требований человеческого развития, сулящих будущему «царство справедливости» [...] Так ли это? Где порука, что заменою общечеловеческой нравственности особой «народовольческою моралью» достигается благо человечества, что трупы-мост к царству справедливости, что «научный социализм» непогрешим и открывает обетованную землю? (Щербань, 1887а: 52 ).

Для Щербаня «социальный вопрос в той форме, в которой ставит его [...] „партия народной воли“» был «игрой своекорыстного честолюбия литературных и иных проходимцев»; «научный социализм»«возвращением в перл создания лени, зависти, ненависти, злобы, всех неприглядных свойств, дремлющих в тайниках человеческого сердца», «облечением животных инстинктов научным костюмом, прикрытием философскою мантией социальной похоти» (там же: 53).

Публицист отмечал, что возбуждение общественного негодования после серии террористических актов уже в 1870-х гг. привело к изоляции нигилизма, а следствием «хождения в народ» стало то, что «безнадежность нигилистического волокитства за сельским населением выяснилась наглядно и осязательно». Именно это привело к серьезной трансформации революционного движения: «нигилизм набросился на мастеровых и рабочих». Но и эта трансформация, по мнению Щербаня, была обречена. Даже на Западе заявленная Марксом солидарность с парижской коммуной только оттолкнула английских рабочих от революционного движения (Щербань, 1887b: 588). Как следствие,

не истый французский мастеровой и фабричный, не рабочий, а тот искусственно сфабрикованный социалистической пропагандою выродок, который известен под кличкой sublime различных подразделений, вот кто даже во Франции составляет контингент революционной армии, готовый ринуться на завоевание «царства справедливости», то есть на порабощение всего сущего себе и своим худшим инстинктам (там же: 593-594). 
Обречен был революционный марксизм (который Шербань не отделял еще от народничества) и в России - уже в силу того, что был стремлением

к насильственному «неумолимому» перевороту в пользу единственно мастеровых и фабричных [...] в пользу класса, численность которого сами социалисты-революционеры определяют в девятьсот пятьдесят четыре тысячи девятьсот семьдесят человек, то есть менее чем в один процент всего стомиллионного населения; в пользу и посредством класса, о котором подстрекатели сами говорят, что «половина его работает на фабриках временно и чуть не случайно, а три четверти - вовсе не пролетарии», который следовательно даже и не составляет революционного элемента, но который нигилизму хотелось бы прибрать к рукам, чтобы посредством его властвовать над народом и приводить в исполнение свои затеи (Щербань, 1887b: 587 ).

Но главной причиной были, конечно же, лояльность и здравомыслие русского простонародья:

«Скрутить»-то русский рабочий люд нигилизму и не удалось. Русский фабричный приведенного выше нигилистического рисунка, трактирный завсегдатель, сподручный для нигилизма «горлан», «коновод» деревенской оппозиции, просвещенный кабацкими «сведениями» и знакомством с «распутными женщинами» - это меньшинство. В большинстве собственно рабочих слишком много веры в Бога, доверия к правительству, совести, да наконец и сметки, чтобы поддаваться «вздору». Не удалось нигилизму создать на Руси sublime! (там же: 597-598).

\section{В силу этих причин}

нигилизм не проник ни в общество, ни в сельское население, ни в рабочий класс. Нигилизм, - это дерево, правильнее - ствол, без корней. Нигилисты, это даже не партия, а шайка, группа, кружок; это кучка отщепенцев и отверженцев, которые могут бросить бомбу из засады, могут, подскочив на готовой умчаться пролетке, неожиданно поразить беззащитного человека: но за засадой, но за пролеткой, но за собою-не имеют никого, кроме нескольких пособников преступления... (Щербань, 1887a: 6o8).

Вслед за Достоевским Щербань описывал тоталитарный характер левого движения. Так, народовольческий кружок претендовал «на гегемонию посреди всех вообще нигилистов, на начальственное к ним отношение, исключающее малейшую критику ее действий и программ», при этом в «начальстве» этого кружка видел «беспредельное самообожание и страстную нетерпимость [...] преследующих всякое сомнение в его непогрешимости» (Щербань, 1887b: 617). Не имея практически 
никакого представления о партийной жизни будущих марксистов, публицист в целом верно предугадал ту атмосферу, что вскоре будет царить на их съездах: «Взаимная подозрительность красною ниткою проходит через все так называемое русское революционное движение. Марксисты печатно прославляли шпионами Бакунина и Герцена; Ткачев печатно объявил в 1874 г. шпионом П. Лаврова» (Щербань, 1887b: 618). В заключительной части своего памфлета публицист изобразил целую галерею портретов нигилистов - от Карказова и Нечаева до безымянных «идеальных типов», диагностировав у них самые различные разновидности фанатизма: от «тупого фанатизма неповоротливой натуры с ограниченным умом и бурной волей» до «фанатизма врожденного ехидства», «ненависти к начальству, собственной начальственной похоти, вожделения господства» (Щербань, 1887с: 78).

Досталось от Николая Васильевича и теоретикам русской революции. Первые учителя нигилизма - Бакунин, Ткачев, Писарев, Добролюбов, Чернышевский, - по его мнению, «не создали никакого положительного учения» (Щербань, 1887b: 624). Из современных ему теоретиков революции Щерабнь мог указать только П. Л. Лаврова и Л. А. Тихомирова. Первый, по мнению публициста, был

посредственность себе на уме, которая будучи не в состоянии прославить себя вкладом в действительную науку, [...] но желая во что бы то ни стало играть роль, создает ее для себя по принципу је suis leur chef, done je les suis: заискивая в самых дурных страстях и потакая самым низким инстинктам (там же: 626).

Тихомиров же предстает в памфлете Щербаня как «обычный распорядитель», плохой публицист, слабо знакомый с западной литературой. (там же: 627). «Убогость нигилистического генералитета» (Щербань, 1887с: 47) привела к тому, что

отцы-командиры, позволяющие себе распоряжаться судьбой уверовавших в них мальчиков и мечтающие о захвате в свои руки судеб России, сами в глубине души сознают свою несостоятельность: когда в начале 1883 года им понадобилась особенно убедительная для России революционная брошюра, с просьбой написать ее они обратились [...] к находившемуся тогда еще в живых Марксу!.. (Щербань, 1887b: 628).

Таким образом, младшие представители катковского круга рисовали весьма плачевную картину русского революционного движения 1880х. Была ли эта картина неверной, или именно в этой-прежде всего, 
духовной-слабости и заключалась сила, одна из причин победы революции,- дело вкуса читающего. Впрочем, борьба с нигилизмом не всегда способствовала усилению и консолидации собственно охранительных сил. Даже А. В. Богданович в конце марта 1881 г. так отзывалась о настроении «катковца» Б. М. Маркевича: «У него одна песня-везде он видит „красных“. Это нехорошо» (Богданович, 1881: л. 45об.). Обвиняя в нигилизме либералов, консервативные публицисты все чаще усматривали лево-радикальные тенденции и в своих рядах.

\section{СОКРАЩЕНИЯ}

РГИА Российский государственный исторический архив.

\section{Источники}

\section{РукописныЕ ИСточники}

Богданович А. В. Дневник // РГИА. - 1880. - Ф. 1620. - Ед. 235.

Богданович А. В. Дневник // РГИА. - 1881. - Ф. 1620. - Ед. 237.

\section{ОПУвлИКовАНнЫЕ ИСтОчники}

Голицын Н. Н. По прочтении депеши. - СПб. : Тип. М. М. Стасюлевича, 1879. Катков М.Н. Несколько слов вместо «Современной летописи»// Русский вестник. - 1861. - № 1. - С. 483-484.

Тихомиров Л. А. Критика демократии. - М. : Москва, 1997.

Цион И. Ф. Пятнадцать лет республике // Русский вестник. - 1885a. - № 8. C. $461-517$.

Цион И. Ф. Пятнадцать лет республике // Русский вестник. -1885 b. - № 9. C. $153^{-184}$.

Цион И. Ф. Нигилисты и нигилизм. - М. : Университетская типография, 1886. Щербань Н. В. Политический разврат // Русский вестник. - 1887а. - № 9. - С. $9^{-}$ 60.

Щербань Н. В. Политический разврат // Русский вестник. - 1887b. - № 10. C. $574^{-628}$.

Щербань Н. В. Политический разврат // Русский вестник. - 1887с. - № 12. C. $47^{-9} 97$.

\section{ЛИTEРATУРA}

Котов А. Э. Профессор Н. А. Любимов: технократ на службе «властной вертикали» // Россия и мир: гуманитарные проблемы. Т. 18. - СПб. : СПбГУВК, 2012. - С. 195-208.

Котов А. Э. П. П. Цитович против «живой воды» революционной демократии // Вестник Тверского государственного университета. Серия: История. 2015. - № 4. - C. 126-134. 
Котов А. Э. «Великая идея всероссийзма»: политическая публицистика М. Ф. Де-Пуле // Вестник Воронежского государственного университета. Серия: История. Политология. Социология. - 2016а. - № 1. - С. $54^{-} 59$.

Котов А. Э. «Царский путь» Михаила Каткова: идеология бюрократического национализма в политической публицистике 1860-1890-х годов. - СПб. : Владимир Даль, 2016b.

Kotov, A. E. 2018. "Publitsisty katkovskogo napravleniya protiv levogo radikalizma (vtoraya polovina 188o-kh gg.) [Publicists of Katkov's Line against the Left Radicalism (Second Half of the 1880s)]" [in Russian]. Filosofiya. Zhurnal Vysshey shkoly ekonomiki [Philosophy. Journal of the Higher School of Economics] II (2), 33-47.

\title{
ALEKSANDR Kotov \\ Doctor of Letters in History, Associate Professor at St. Petersburg State University (Russia) \\ Publicists OF KatKov's Line against the LefT RADICALISM (SECOND HALF OF THE 1880S)
}

\begin{abstract}
M. N. Katkov considered assisting the authorities in the fight against the revolution to be one of the main tasks of the conservative press. Initially, Katkov believed Russian nihilism to be a consequence of the Polish intrigue. But first attempts of revolutionaries to kill Alexander II showed that the revolution is of an inward nature. By the end of the 186os, the theme of the Polish intrigue fades away from the antinihilistic discourse. Both Katkov and his staff were looking for the roots of the revolution within Russian society itself. At the turn of the 1870 s -1880 s, anti-revolutionary pamphlets written by N. A. Lyubimov, N. N. Golitsyna, P. P. Tsitovich, M. F. De-Poulet had a great resonance. But there were pamphlets of a different kind in this period. One of them was Review of the Social-Revolutionary Movement in Russia by S. S. Tatischev. The publication was not intended for the general public, and this gave the author some freedom (in particular, he recognized the validity of some theses stated by the ideologists of socialism), but he regarded Russian nihilists as misfits. I. F. Cyon's approach was similar. Since mid-1870's Cyon lived abroad, thus he, too, had an opportunity to see Russian revolutionism within the European context. The establishment of the republic in France had only proved, in his opinion, all the feebleness of the Left. Equally contemptuous of the French republicans was Katkov's main correspondent in Paris, N. V. Shcherban. In his correspondence he drew a vivid panorama of the revolutionary events of the early $1870 \mathrm{~s}$. In 1887, he published his pamphlet entitled Political Debauchery, attacking both Narodnaya Volya with their theoreticians and Marxist ideas penetrating into the Russian revolutionary milieu. Relying on the materials of the émigré press, Shcherban convincingly demonstrated the weakness of the theory of revolutionary nihilism.
\end{abstract}

Keywords: Conservatism, Nihilism, Revolution, Marxism, Populism, M. N. Katkov, N. V. Shcherban.

DOI: $10.17323 / 2587-8719-2018-I I-2-33-47$. 


\section{REFERENCES}

Bogdanovich, A. V. 1880. "Dnevnik [Diary]" [in Russian]. In RGIA [Russian State Historical Archive]. 1620/235.

- . 1881. "Dnevnik [Diary]" [in Russian]. In RGIA [Russian State Historical Archive]. $1620 / 237$.

Golitsyn, N. N. 1879. Po prochtenii depeshi [After Reading the Despatch] [in Russian]. Sankt-Peterburg [Saint Petersburg]: Tip. M. M. Stasyulevicha.

Katkov, M. N. 1861. "Neskol'ko slov vmesto 'Sovremennoy letopisi' [A Few Words instead of the 'Modern Review']" [in Russian]. Russkiy vestnik [Russian Herald], no. 1: 483-484.

Kotov, A. E. 2012. "Professor N. A. Lyubimov: tekhnokrat na sluzhbe 'vlastnoy vertikali' [N. A. Lubimov: A Technocrat in the Service of the Top-Down Governance]" [in Russian]. In Rossiya i mir: gumanitarnyye problemy [Russia and World: Himanitarian Issues], 18:195-208. Sankt-Peterburg [Saint Petersburg]: SPbGUVK.

- .2015. "P. P. Tsitovich protiv 'zhivoy vody' revolyutsionnoy demokratii [P. P. Citovich against the 'Aqua Vita' of the Revolutionary Democracy]" [in Russian]. Vestnik Tverskogo gosudarstvennogo universiteta. Seriya: Istoriya [Bulletin of the Tver State University. Series: History], no. 4: 126-134.

Shcherban', N. V. 1887a. "Politicheskiy razvrat [Political Debauchery]" [in Russian]. Russkiy vestnik [Russian Herald], no. 9: 9-6o.

- . 1887b. "Politicheskiy razvrat [Political Debauchery]" [in Russian]. Russkiy vestnik [Russian Herald], no. 10: 574-628.

- . 1887c. "Politicheskiy razvrat [Political Debauchery]" [in Russian]. Russkiy vestnik [Russian Herald], no. 12: 47-97.

Tikhomirov, L. A. 1997. Kritika demokratii [Criticism of Democracy] [in Russian]. Moskva [Moscow]: Moskva.

Tsion, I. F. 1885a. "Pyatnadtsat' let respublike [15 Years of Republic]" [in Russian]. Russkiy vestnik [Russian Herald], no. 8: 461-517.

- . 1885b. "Pyatnadtsat' let respublike [15 Years of Republic]" [in Russian]. Russkiy vestnik [Russian Herald], no. 9: 153-184.

- . 1886. Nigilisty i nigilizm [Nihilists and Nihilism] [in Russian]. Moskva [Moscow]: Universitet.skaya tipografiya.

Kotov, A. E. 2016a. "Velikaya ideya vserossiyzma': politicheskaya publitsistika M. F. De-Pule ['The Great Idea of Vserossiyzm [All-Russianness]': M.F. De-Poulet's Political Essays]" [in Russian]. Vestnik Voronezhskogo gosudarstvennogo universiteta. Seriya: Istoriya. Politologiya. Sotsiologiya [Proceedings of Voronezh State University. Series: History. Political Science. Sociology], no. 1: 54-59.

- . 2016b. "Tsarskiy put" Mikhaila Katkova: ideologiya byurokraticheskogo natsionalizma $v$ politicheskoy publitsistike 1860-189o-kh godov [Mihail Katkov's "the Road of the Czar": Ideology of the Bureaucratic Nationalism in the 1860-189os Political Essays] [in Russian]. Sankt-Peterburg [Saint Petersburg]: Vladimir Dal'. 